\title{
Tradition and modernity in Władysław Sowicki's pre-war architecture of exposition pavilions
}

\section{Agata Wereszczyńska}

\begin{abstract}
The paper discusses three architectural concepts of exposition pavilions authored by Władysław Sowicki. Each of them represents a different style, but all of them follow the design trends of their time. The first one is the Polish pavilion for the 1937 World Expo in Paris, and as such it alludes to the Polish national style. The second one is another Polish pavilion, this time semi-modernist, designed for the 1939 New York World's Fair. The last building was designed for the "Order" Artists' Cooperative [Spółdzielnia Artystów Ład] in the same year (1939) and is a great example of the compromising semi-modernism of the late 1930s. The concepts discussed in this paper are excellent examples of how traditional, decorative esthetics, so typical of the Polish school of design and national art in general, and the contemporary quality of the avantgarde and modernism permeate each other, as Sowicki skillfully employs characteristic features of both these trends and fuses them in one coherent design.

The main research method applied for the purposes of this paper is analysis of visual material from the archive of Władysław Sowicki's family, archive and library research, review of aca-demic literature on the subject, as well as analysis of the evolution of architectural styles and trends in the period in which the discussed buildings were designed.

Sowicki's architectural works described in the article had a temporary character, they were dedicated to represent exact entities in a specific place and time and did not mark the architectural landscape permanently because the length of their duration was tightly deter-mined. The intention of the author was to compare the discussed projects with similar Polish architectural works that were created in approximately the same period and had akin formal and stylistic character. The author also wanted to prove that the works of Władysław Sowicki were in line with the Polish architectural context in the late thirties of the interwar period.
\end{abstract}

\section{Introduction}

Design styles which coexisted in the interwar period differed significantly from one another, both in terms of esthetics and content. Indeed, synthetic presentation of form and its geometrization was how art déco reacted to art nouveau, functionalism negated the ornamentality of eclectic forms, whereas the semi-modernism of the late 1930s was a response to the harsh austerity of functionalism, as it dared to complement simple solids with soft outlines and elegant decoration. In fact, one might even call this situation "the rivalry of styles" [Benton 2010, 427]. It was observed around the world, but also in Poland. Carefully monitoring globally changing trends, Polish architecture eagerly and promptly responded to international modifications and novelties by transposing them to serve local needs. The 1920s saw the birth of the very specific Polish national style based on characteristic local features. It combined a modern approach to design with local folk tradition and it was termed Polish art déco, or "national modernism" [Miłobędzki 1968, 310]. At the same time, modernism developed rather intensely, mainly as an opponent of the Polish national style, criticizing it as offering all too pastoral solutions and an obsolete approach to design [Szczuka 1925, 1]. 


\section{TRADITION AND MODERNITY IN WŁADYSŁAW SOWICKI'S PRE-WAR ARCHITECTURE OF EXPOSITION PAVILIONS}

Agata Wereszczyńska

The radical face of modernism, namely functionalism, was not reflected in Sowicki's works, therefore it is not discussed in this paper. The second half of the 1930s, especially the very last years of that decade, was the blooming period of compromising semi-modernism and its soft, streamlined shapes. Designers decided to revisit ornamentality which was reflected in architectural detail, texture of the material used and a more expressive approach to constructing architectural forms [Wereszczyńska 2015 (2), 34].

The aim of this work is to discuss and present, against the backdrop of Polish architecture in general three architectural concepts of exhibition structures authored by Władysław Sowicki in the late 1930s ${ }^{1}$. Each of them follows a different style of the interwar period - the pavilion for the 1937 Paris World Expo represents the Polish variant of art déco, the pavilion for the 1939 New York World's Fair observes the principles of geometric late modernism, whereas the pavilion designed for the "Order" Artists' Cooperative [Spółdzielnia Artystów Ład] from 1939 represents the semi-modernism of the late 1930s.

As an architect, Władysław Sowicki was strongly influenced by Polish applied arts, the assumptions of which laid the foundations of his education in the State School of Decorative Arts and Artistic Industry [Państwowa Szkoła Sztuk Zdobniczych i Przemysłu Artystycznego] in Cracow, followed by studies in the Academy of Fine Arts in Warsaw. Sowicki's membership in the "Order" Artists' Cooperative [Spółdzielnia Artystów Ład] also reveals to us the direction of his design-related interest. If we analyze the architect's works, we will surely recognize elements of the Polish national style in his concepts from before and after World War II. On the other hand, there are also references to the aesthetics of late modernism which appeared in Sowicki's designs when he started studies at the Faculty of Architecture of the Warsaw University of Technology². In general, Władysław Sowicki's

\footnotetext{
${ }^{1}$ Władysław Sowicki was born in 1911 in Bieżanów, a small village located between Kraków and Wieliczka, in the area controlled by the Austrians after the Partitions of Poland. He completed a secondary school in Wieliczka; then in 1929-1934 he attended the National School of Decorative Arts and Artistic Industry [Państwowa Szkoła Sztuk Zdobniczych i Przemysłu Artystycznego] in Cracow (he graduated from the General Faculty and the Specialised Faculty of Interior Architecture). Between 1929 and 1932, he was a member of Szczep Rogate Serce [Tribe of the Horned Heart], an artistic group established by Stanisław Szukalski. During the years 1934-1938 he studied at the Academy of Fine Arts in Warsaw, and graduated in Interior Architecture. In 1935, he joined the "Order" Artists' Cooperative [Spółdzielnia Artystów Ład]. In 1938, he began to study at the Faculty of Architecture of the Warsaw University of Technology. In 1939, Sowicki started to work as a junior assistant at the Department of Interior Architecture of the Warsaw Academy of Fine Arts where he held classes on Composition of Solid Figures and Planes. In the same year, he married Maria Szczygłówna. During the war he lived in Warsaw, and had a permission to perform the job of interior architect and decorator (Innenarchitekt-Dekorateur, Erlaubniskarte no. 459/K). After the Warsaw Uprising, he was sent to the transit camp in Pruszków, from which he managed to escape. After the war, he moved to Łódź. He also belonged to the Łódź Chapter of the Association of Polish Artists and Designers (ZPAP), the Polish Society of Authors and Composers "ZAiKS", cooperated with the Production Esthetics Supervision Authority and with Cepelia. Sowicki had two daughters - Barbara and Magdalena. He died in 1954 (at the age of 43) and was buried at the Old Cemetery in Łódź [cf. Wereszczyńska 2015, 28-45].

${ }^{2}$ During the second half of the interwar period, the curricula of Warsaw higher education facilities - the Academy of Fine Arts and the Faculty of Architecture of the Warsaw University of Technology - differed significantly. The former focused on the "formation of the Polish national art on the basis of modernized inspirations from the Polish folk culture" (the so-called Cracow School), while the latter aimed at "popularization of functionalism and the avantgarde" (the so-called Warsaw School) [cf. Wereszczyńska 2015, 41].
} 
design practice followed the direction - and changes - of general design trends. His oeuvre was clearly inspired by various tendencies, but he was consistent in combining tradition with modernity in his own signature style which interpolated modernist forms into the characteristic esthetics of Polish design.

\section{Design no.1 - the finesse of art déco}

The first work authored by Władysław Sowicki discussed in this paper is the concept of the Polish pavilion for the World Expo held in Paris in 1937 under the banner "Art and Technology in Modern Life". The design was submitted as an entry to the contest organized in 1936 and it follows the spirit of the Polish variant of art déco (pic. 1, 1a)

\section{Pic. 1, 1a. Scale model of the exposition pavilion for the World Expo in Paris 1937, 1936}
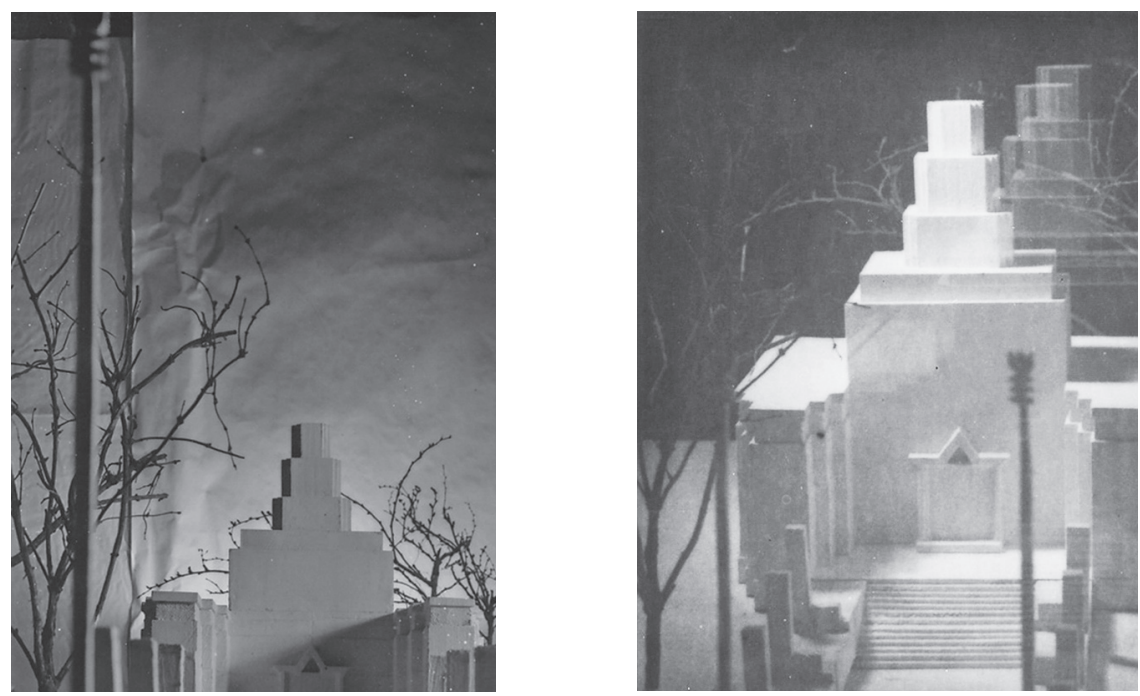

Source: Władysław Sowicki family archive

The history of Polish applied arts of the interwar period in fact begins already in the late 19th century in the Polish highland region of Podhale. There, Stanisław Witkiewicz was the one to start what was later to be labelled the Polish national style. Inspired by the international Arts and Crafts Movement, he developed the so-called Zakopane style, based on the folk culture and arts of the Podhale highlanders. The founding of the Polish Applied Arts Society [Towarzystwo Polska Sztuka Stosowana] in Cracow in 1901 was the next crucial step to further the expansion of Polish applied arts. The Society aimed to, among other things, align functional arts with artistic craftsmanship and rank them among proper arts (it should be remembered that the dawn of the 20th century was a time when arts were categorized into "higher" (architecture, painting, sculpture) and "lower" (decoration) ones) [Huml 1978, 57]. The following years saw the emergence of other groups which also significantly contributed 

EXPOSITION PAVILIONS

Agata Wereszczyńska

to driving Polish applied arts into full bloom. In 1909 the ARMiR artistic association (ARMiR being the Polish acronym for: Architecture, Sculpture, Painting and Craftsmanship) was set up, based on the postulates of the Arts and Crafts Movement, promoting the thesis of cooperation between all types of arts. In 1913 another organization motivated by similar assumptions was established, namely Cracow Workshops [Warsztaty Krakowskie] which attracted artists, designers and craftsmen. The aim of the group was to facilitate integration of arts with crafts, assign equal status to all the arts, but also to search for the style of Polish national art. Cracow Workshops proved to be one of the formations that managed to set a course for the development of Polish applied arts, mainly through their major international success in 1925, when the Polish pavilion for World Expo Paris was presented, designed in accordance with the principles of the Polish variant of art déco. It should be mentioned here that there were a few important groups which strongly influenced the ambitious process of shaping the framework of Polish decorative arts, both before and after World War II, and one of the most prominent of these was the "Order" Artists' Cooperative [Spółdzielnia Artystów

\section{Pic. 2. Exposition pavilion for the World Expo in Paris designed by Józef Czajkowski, 1925}

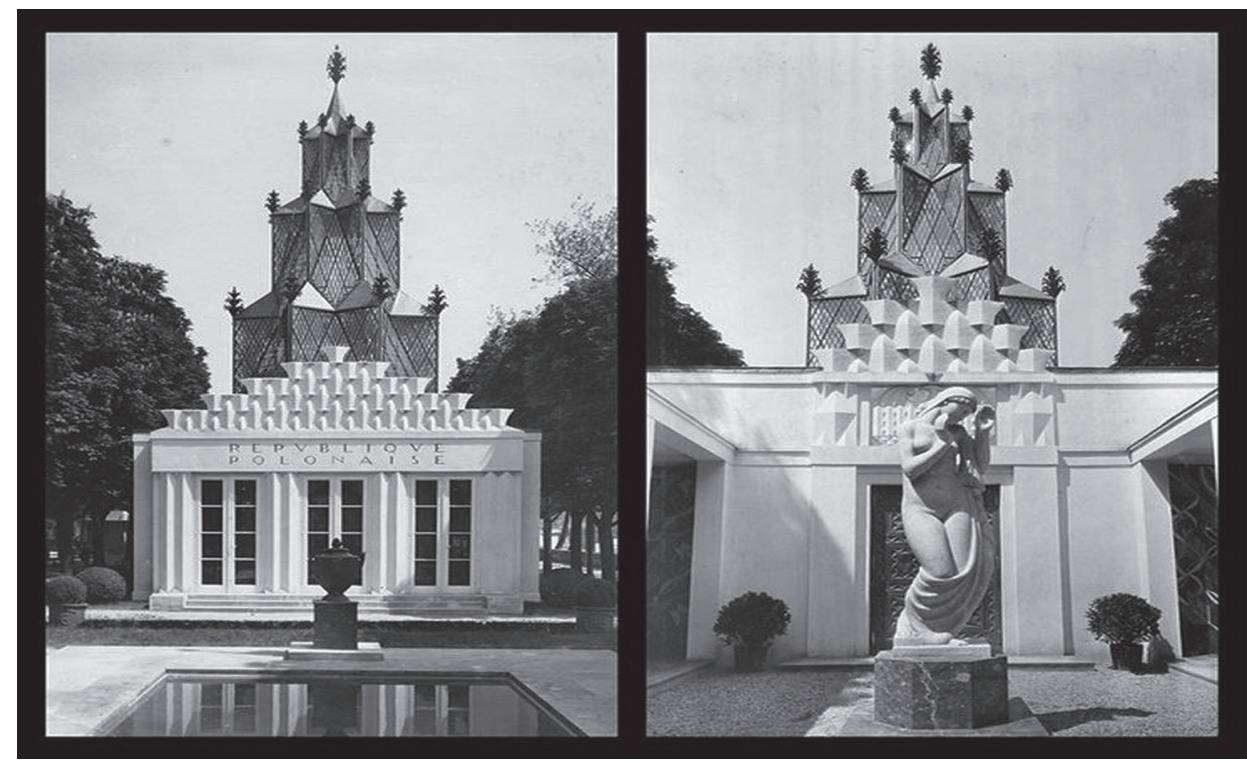

Source: https://s-media-cacheak0.pinimg.com/736x/0b/83/e3/0b83e37ac6ebf2a48a64e08a4d7bd1ba.jpg

Ład] established in 1926 in Warsaw. The Cooperative aimed to encourage harmonious interior design, based on a skillful combination of forms and colors and on putting the traditional alongside the contemporary in what could be referred to as modernized folklore. In fact, all the design movements mentioned here significantly contributed to the development of the Polish functional art style, with its very characteristic compilation of Polish folk motifs, such as distinct notch corners and the geometric form of triangular crystal-like structures, which 
earned this style the name "kryształkowy" (it was also referred to as "kozikowy" style, triangular manner, 1925 style or “jastrzębowszczyzna"3)

The pavilion designed by Władysław Sowicki features a number of elements representative of the approach discussed above. The whole complex consists of a long alley flanked with tall flagpoles leading to the main building which is crowned with a monitor cupola roof, the dominant feature of the entire structure built upon the accumulation of solid masses. The building is surrounded by a lower edifice with articulated, stair-step outer walls. The crown of the complex shaped like a stepped pyramid brings to mind crystal-like forms. In fact, this solution was applied rather frequently in similar structures designed in the same period. Articulation of the elevation and the tall spire topping it are undoubtedly inspired by the design practice of the leading Polish architects. Other exposition pavilions might serve as an example here, for instance the Polish pavilion for the 1925 Paris World Expo mentioned above, designed by Józef Czajkowski, with the dominant spectacular crystal-like glass tower (pic. 2), or Roger Sławski's concept of the tower of the Representation Hall [Hala Reprezentacyjna] from 1927 (pic. 3), or, eventually the Pavilion of the Polish Association of Glassworks [Polski Związek Hut Szklanych] designed by Jan Goliński and Henryk Łagowski ${ }^{4}$ - glass architecture crowned with a glass spire [Kubiak 2014, 161] (pic. 4). Sowicki's design discussed in this section of the paper also employs other elements of the style - variable language of façade elements, play of light and shadows, triangular interpenetrations, decorative geometrical forms as well as expressionist theatre-like light effects.

\section{Pic. 3. Roger Sławski's concept of the tower of the Representation Hall for the Polish General Exhibition, Poznań 1929}

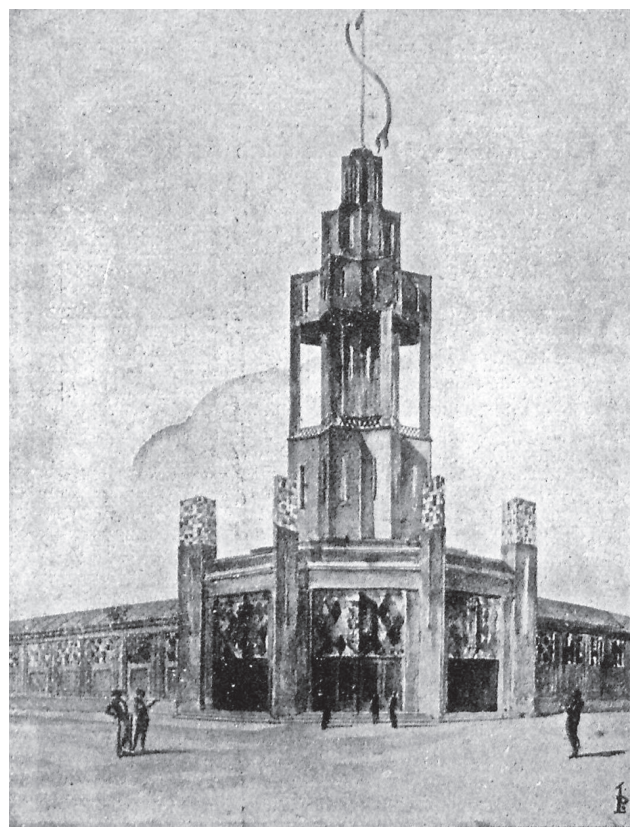

Source: S. P. Kubiak, Modernizm zapoznany.

Architektura Poznania 1919-1939,

Fundacja Centrum Architektury, Warszawa 2014, p.158

\footnotetext{
${ }^{3}$ The term "jastrzębowszczyzna" refers to the name of one of the most prominent representatives of Polish applied arts in the interwar period, Wojciech Jastrzębowski.

4 The last two were designed for the Polish General Exhibition 1929 in Poznań.
} 

EXPOSITION PAVILIONS

Agata Wereszczyńska

\section{Pic. 4. Pavilion of the Polish Association of Glassworks designed by Jan Goliński and Henryk Łagowski for the Polish General Exhibition, Poznań 1929}

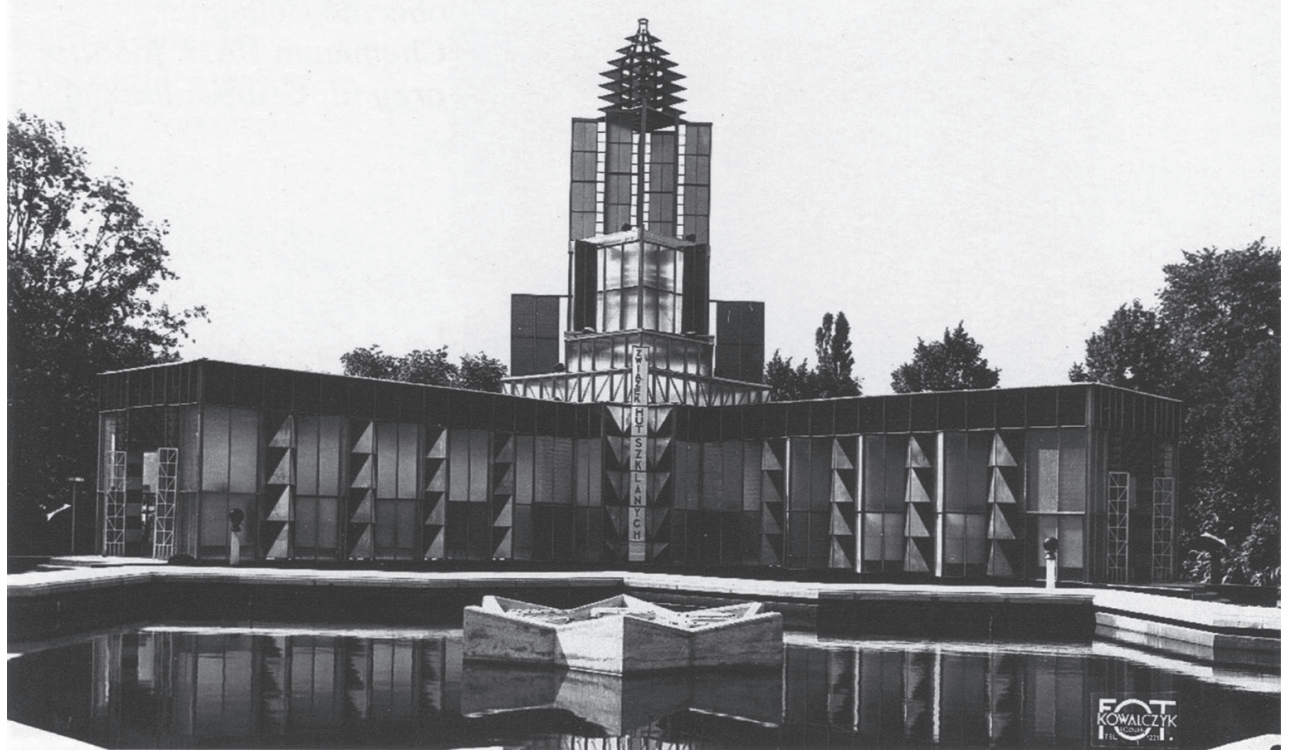

Source: http://www.wieczorkiewicz.org/mid/pawilon-zwiazku-hut-szklanych-1929-001.jpg

\section{Design no. 2 - geometry of late modernism}

Just like it happened around the world, the reality of Polish architecture of the late interwar period began to divert from the functionalist axiom. As a result, cosmopolitan and coherent solutions, obligatorily simplified forms, functions and structures of functionalism were gradually replaced with individuality and originality adjusted to local conditions. Obviously, this did not imply a return to buildings detached from their structure or affected decorationism, but it definitely meant that "the paradigm of modernity has changed - the fixed structure of architectonic forms ceased to be seen as a synonym of progress" [Wereszczyńska 2015, 51]. This variety of avantgarde architecture is sometimes referred to as free functionalism or new regionalism [Olszewski 1967, 27, 31].

The exposition pavilion designed by Władysław Sowicki (in cooperation with Henryk Tomaszewski) as an entry to the contest held in celebration of the 1939 New York World's Fair (with a slogan of "Dawn of a New Day") has certain features characteristic of functionalism - straight, box-like forms contrasted with the rounded geometry of a cylinder (pic. 5, 5a). At the same time, it also refers to the new course taken by architecture. It is no longer pure functionalism, an architecture-machine which refuses to accept any ornamental features, but it still lacks the finesse of putting together soft, wavy lines with right angles, as is the case 
Pic. 5a. Scale model of the exposition pavilion for the World Expo in New York 1939

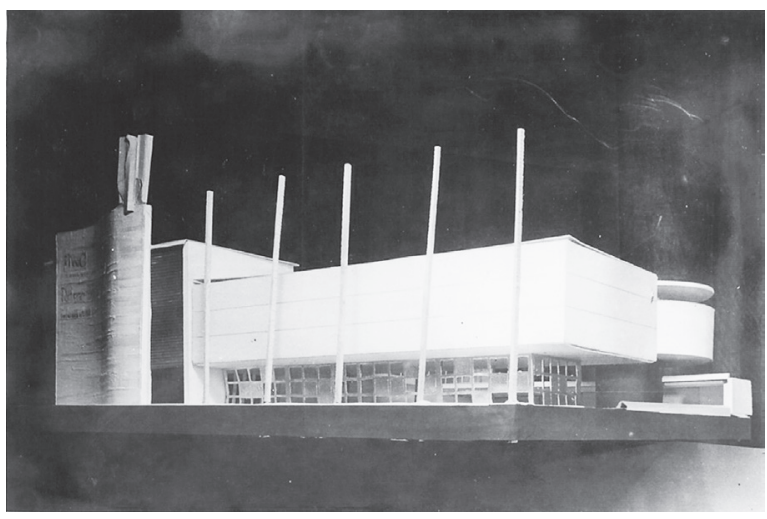

Source: Władysław Sowicki family archive in the third design discussed in this paper. The decorative layer clearly alludes to the Polish art déco style.

The whole pavilion complex consists of low geometric solids set together in a dynamic, horizontal U-shaped layout with an internal half-open yard with water and plants. The aforemen-tioned reference to Polish art déco is visible in the form of the entrance wall. Soft, irregular lines, rough textures and the stylized eagle sculpture over the entrance unambiguously evoke the free decorativeness of the Polish functional art of the 1920s. It is also reflected in the

delicate openwork wall of the ground floor and the curtain wall on the first floor of one of the "boxes". The architectonic language of other forms constituting the concept was reduced to the minimum.

The design by Sowick \& Tomaszewski shows incredible coherence with other concepts sub-mitted for the contest. They are all focused on the combination of box-like forms with one expressly accented circular block. The works which were awarded also applied such solutions, namely those by Stefan Osiecki, Lucjan I. Piętka, Jerzy Skolimowski, Eugeniusz Szparkowski and Wacław Hryniewicz (1st place), Jan Bogusławski and Maciej Nowicki (2nd place), Jan Cybulski, Jan Galinowski and Felicjan Kowarski (3rd place) [Konkurs powszechny Nr 95... 1938, 77-82]. Indeed, beside modernized classicism, geometric abstraction seems to be the main motif of the whole World's Fair in New York in 1939, to mention just the most characteristic structure of that event which is still recognized as the symbol of the New York expo, namely the Theme Center with the futuristic Perisphere floating above the water and the soaring Trylon, both created by the Harrison \& Fouilhoux studio

\section{Pic. 5b. Scale model of the exposition pavilion for the World Expo in New York 1938}

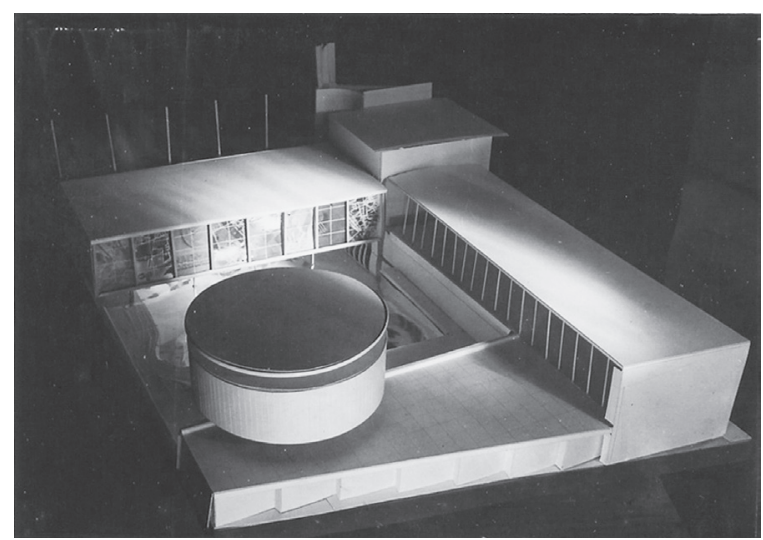

Source: Władysław Sowicki family archive 

EXPOSITION PAVILIONS

Agata Wereszczyńska

Pic. 6. Trylon and Perisphere designed for the World Expo in New York, 1939

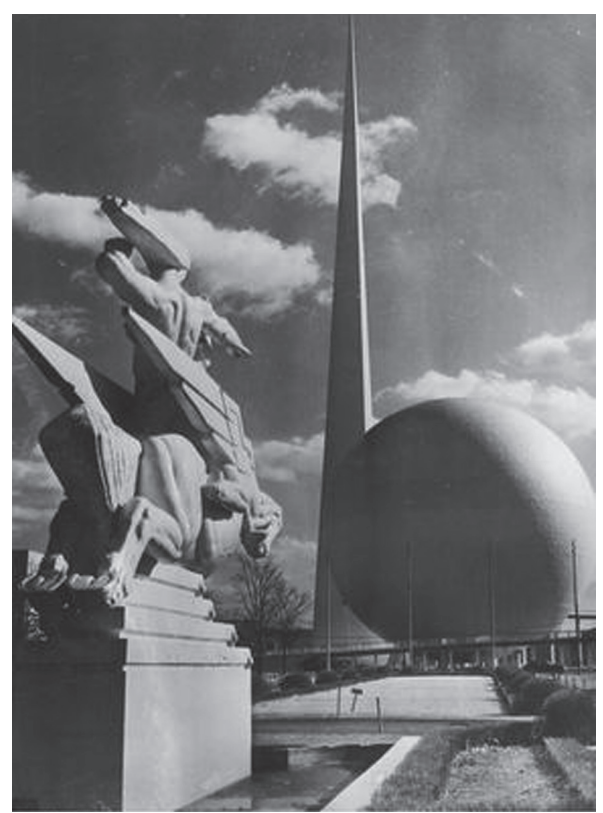

Source: https://audiovis.nac.gov.pl, sygn. 1-M-654-19 (pic. 6) [Nowakowska 2013, 55]. “The Trylon and Perisphere are actually almost like a sculpture which has entered the world of geometric abstraction, and as such, they might be compared to 18th-century designs by Boullèe and Ledoux, but also to the works of the 20thcentury fantasy artists" [Olszewski 2008, 356].

\section{Design no.3 - expression of semi-modernism}

The second half of the interwar period brought certain significant changes in design which substantially influenced the process of shaping the architectonic form and decoration, being a "sort of compromise between the free approach to functionalism and the tendencies to continue regional tradition" [Olszewski 1988, 65]. Box-like forms gave place to streamlined elements. At the same time, a new quality in decorating buildings was introduced expensive, luxurious materials with intriguing textures and subtle patterns began to be used to add chic to compositions.

\section{Pic. 7, 7a. Scale model of exhibition pavilion for "Order" Artists' Cooperative, 1939}
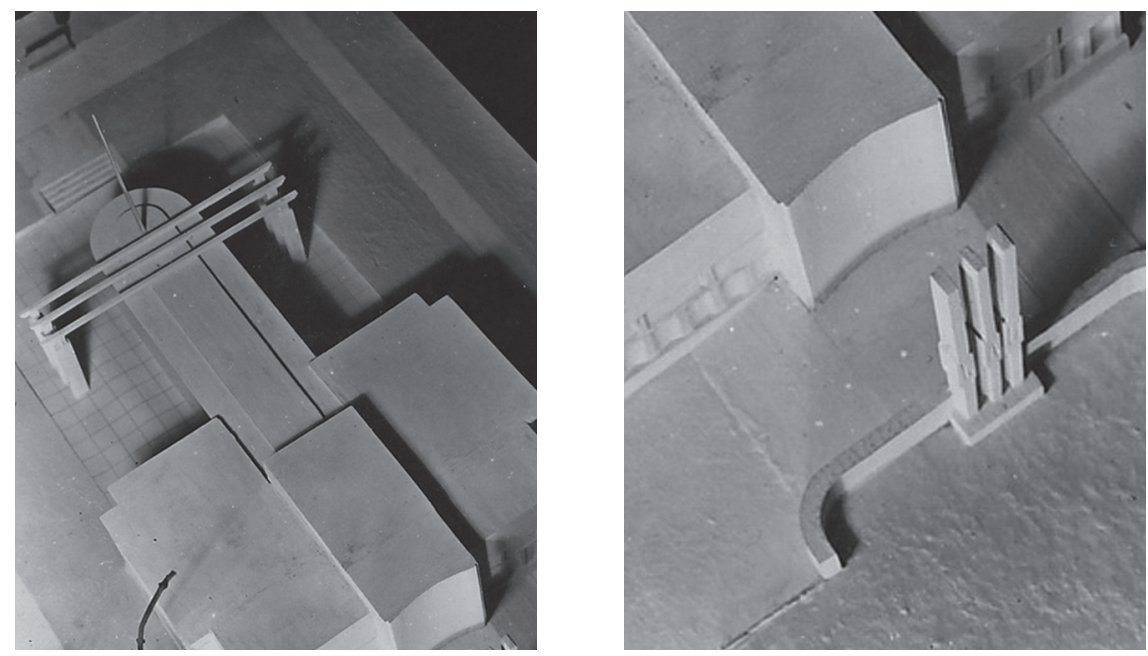

Source: Władysław Sowicki family archive 
The last of Sowicki's designs discussed in this paper is that of the 1939 exposition pavilion for the "Order" Artists' Cooperative [Spółdzielnia Artystów “Ład"] (pic. 7, 7a). The whole structure follows the principles of late modernism, with the dynamic and expressive combination of straight and soft lines, a direct reference to the streamline style blooming in the late 1930s. The liberal use of straight sections and streamlined shapes and incorporating them skill-fully in one concept resulted in exceptionally modern visual effects. Sowicki's

\section{Pic. 8a. Drawing of the Church of Mary Victorious dsigned by Konstanty Jakimowicz, Warszawa 1929-1931}

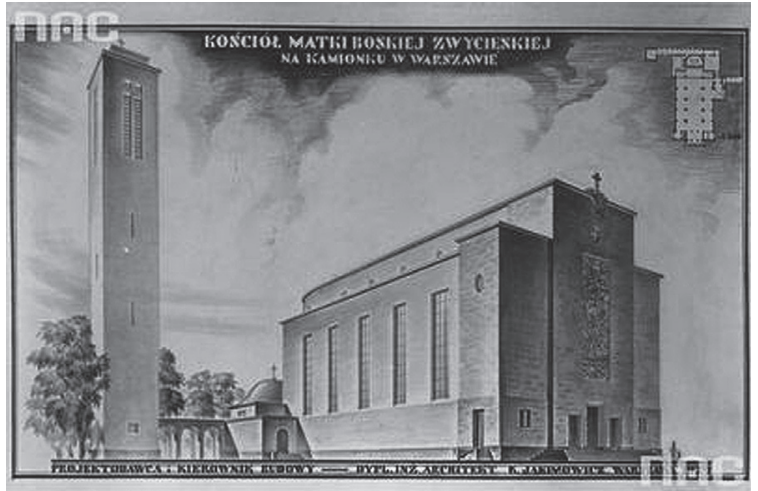

Source: https://audiovis.nac.gov.pl, sygn. 1-U-7015-1 design is based on a symmetrical, axial structure, a three-aisle basilica arrangement with the central nave slightly higher and also two times longer than the flanking aisles. It features a very characteristic element, namely the curved (concave) front wall of the central part, a solution frequently applied in architectural designs of the 1930s. Three flagpoles were put up in front of it, each with one letter, to form the name of the Cooperative, " $€ A D$ ". The decorative form of the flagpoles is evocative of the esthetics of Polish applied arts. The rear elevation of the building is also curved in its central part, which inevitably brings to mind a church presbytery. In the floor plan, it looks as if the sunken front wall thrusted out the rear wall. The building is crowned with a slender spire and a pergola-like form. The large surfaces of smooth walls and frugal decorative detailing are counterbalanced with "soft" forms, thanks to which the building does not look too austere, but at the same time it is not overembellished. In fact, it seems to be very well-proportioned in terms of the application of rectangular and streamlined forms. "The new art is not only perfect for modern churches, it can also be applied in churches built in older styles, as it administers both sharp forms and circles or cylinders" [Rogoziński 1933, 226-306]. Sowicki's inspiration with sacred architecture is visible

\section{Pic. 8b. Drawing of the Church of Mary Victorious dsigned by Konstanty Jakimowicz, Warszawa 1929-1931}

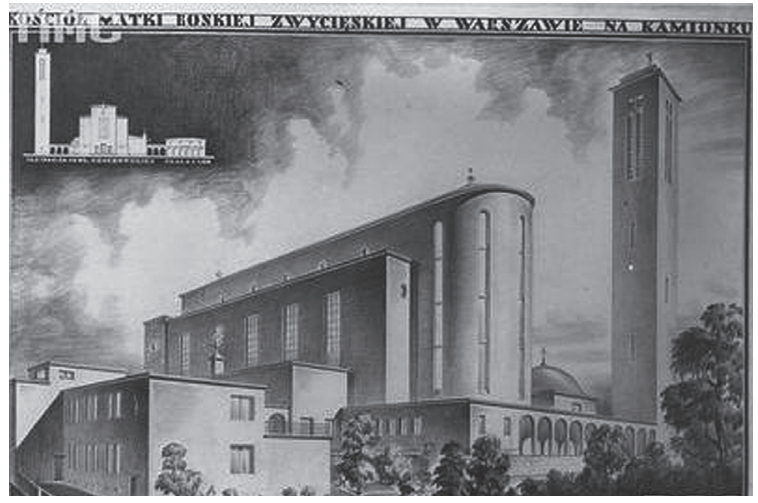

Source: https://audiovis.nac.gov.pl, sygn. 1-U-7015-2 


\section{Pic. 9. Drawing of the Garrison Church designed by Marian Lalewicz, Gdynia 1934-1935}

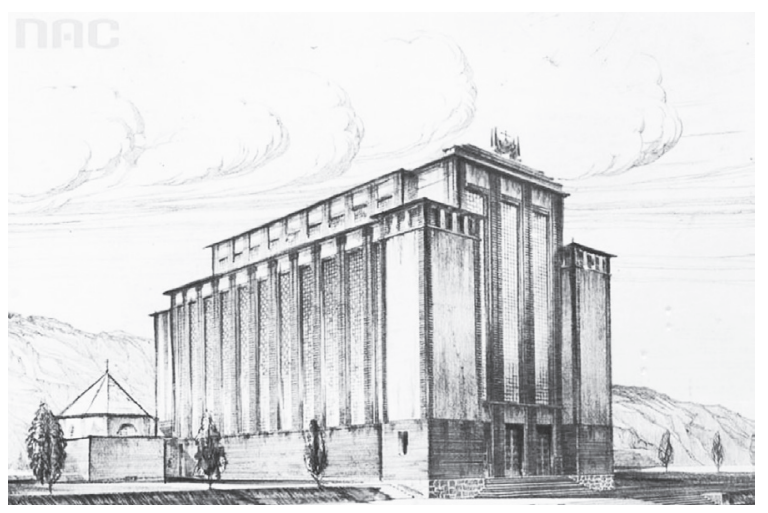

Source: https://audiovis.nac.gov.pl, sygn. 1-U-1154

not only in the floor plan, but also in the walls. The look suggestive of pylon church facades, popular in the 1930s, was achieved by lowering the side naves in relation to the main nave in the elevation plan. This manner of articulating the elevation was frequently employed in the architecture of the late 1930s, for instance in the Church of Mary Victorious (1929-1931), which was designed by Konstanty Jakimowicz (pic. $8 \mathrm{a}, 8 \mathrm{~b}$ ) or in the Garrison Church in Gdynia (1934-1935) designed by Marian Lalewicz (pic. 9). Both are more occlusive, with shorter side naves in the floor plan, and vertically oriented when considered from the elevation perspective, while Sowicki's design was definitely horizontal. Despite these minor differences, the general concept seems to be identical.

\section{Summary}

Designing exposition pavilions is a very special task for an architect, as they are temporary structures, meant to be viewed only in some specific time and place, with a short, butterflylike life. They are to attract the attention of clients and visitors to vast trade areas. At the same time, they are supposed to tell the audience about their purpose, which is why the visual layer is of crucial importance. In terms of architecture, the exposition pavilions designed by Władysław Sowicki seem to be consistent with the tendencies dominating on the Polish and international architectonic scene. Sowicki was neither conservative nor avantgarde. His output in the field of architecture, ${ }^{5}$ originating from Polish folk art, would always balance between tradition and modernity, sometimes only leaning towards one side or the other, but always drawing from both. This fluidity was in line with the general spirit permeating the architectural community, as already in the 1920s people asked themselves whether they should "maintain extreme asceticism in the simplicity of structure and in complete resignation from ornamentation, retaining only the play of plasterwork colors, or maybe instead they should dare to at least round the corners and the balconies wrapping them, and to add some ellipses and circles in horizontal sections" [Faryna-Paszkiewicz 2003, 69]. The ease with which Władysław Sowicki used this rich language of architecture in his designs is

\footnotetext{
${ }^{5}$ The present paper discusses only an excerpt of Władysław Sowicki's creative output. Sowicki was an architect and
artist, whose multi-faceted creative practice involved a wide spectrum of design projects - beginning from architecture,

${ }^{5}$ The present paper discusses only an excerpt of Władysław Sowicki's creative output. Sowicki was an architect and
artist, whose multi-faceted creative practice involved a wide spectrum of design projects - beginning from architecture, through urban planning, interior architecture, furniture, jewelry and toy design, to posters.
} 
an indication of his versatility, sensitivity to constant transformations of design tendencies, but also openness and readiness to change.

In Sowicki's architectural design objects with a temporary character appeared quite often. Apart from trade-fair pavilions the architect also created other projects which were close to the art of exhibition - temporary exhibitions, bazaars or interiors of exhibition pavilions. The majority of these works were designed in the post-war years.

\section{Bibliography:}

Benton C., Benton T., 2010, Zmierzch i odrodzenie (in:) Benton C., Benton T., Wood G., Art Déco 1910-1939, Poznań.

Faryna-Paszkiewicz H., 2003, Geometria wyobraźni. Szkice o architekturze dwudziestolecia międzywojennego, Gdańsk.

Huml I., 1978, Polska sztuka stosowana XX wieku, Warszawa.

Konkurs powszechny Nr 95 na projekt szkicowy Pawilonu Polskiego na Światowej Wystawie w Nowym Yorku w 1939 r., 1938, "Architektura i Budownictwo", issue 3.

Kubiak S. P., 2014, Modernizm zapoznany. Architektura Poznania 1919-1939, Warszawa.

Miłobędzki A., 1968, Zarys dziejów architektury w Polsce, ed. 2, Warszawa.

Nowakowska K., 2013, Pawilon Polski na nowojorskiej wystawie światowej (1939-1940), Warszawa.

Olszewski A. K., 1988, Dzieje Sztuki Polskiej 1890-1980 w zarysie, Warszawa.

Olszewski A. K., 2008, New York 1939, pp. 351-372 (in:) Drexlerowa A. M., Olszewski A. K., 2008, Polska i Polacy na powszechnych wystawach światowych 1851-2000, Warszawa.

Olszewski A. K., 1967, Nowa forma w architekturze polskiej 1900-1925, Wrocław - Warszawa Kraków.

Rogoziński M., 1933, Nowa sztuka wnętrz kościoła, „Głos Kapłański”, pp. 226-306, za: Faryna-Paszkiewicz H., 2003, Geometria wyobraźni. Szkice o architekturze dwudziestolecia międzywojennego, Gdańsk, p. 75.

Szczuka M., 1925, Czy sztuka dekoracyjna?, „Blok”, issue 10.

Wereszczyńska A., 2015, Ewolucja twórczości Władysława Sowickiego (1911-1954) w kontekście rozwoju tendencji architektonicznych $i$ artystycznych lat trzydziestych dwudziestolecia międzywojennego oraz Polski powojennej do roku 1954, doctoral dissertation, Łódź. 


\section{TRADITION AND MODERNITY IN WŁADYSŁAW SOWICKI'S PRE-WAR ARCHITECTURE OF EXPOSITION PAVILIONS}

Agata Wereszczyńska

Wereszczyńska A., 2015 (2), Statki na trawie i kropla wody - styl streamline w architekturze i wzornictwie przemysłowym w latach trzydziestych XX wieku w Stanach Zjednoczonych, Europie $i$ Polsce (in:) „Architecturae et Artibus”, issue 2, pp. 33-45.

\section{Tradycja i nowoczesność w przedwojennych projektach architektury pawilonów wystawienniczych Władysława Sowickiego}

\section{STRESZCZENIE}

W artykule omówione zostały trzy projekty architektury pawilonów wystawienniczych autorstwa Wła-dysława Sowickiego. Każdy obiekt zaprojektowany został w odmiennym stylu, jednakże zgodnie

z obowiązującymi tendencjami projektowymi. Pierwszy z nich, pawilon państwa polskiego na Wystawę Światową w Paryżu w 1937 roku, odwołuje się do języka polskiego stylu narodowego. Drugi, pawilon Polski na Wystawę Światową w Nowym Jorku, która miała miejsce w 1939 roku, został zaprojektowa-ny w estetyce półmodernizmu. Kolejny, trzeci obiekt przeznaczony dla Spółdzielni Artystów Ład, rów-nież z 1939 roku, jest przykładem kompromisowego półmodernizmu końca lat trzydziestych. W oma-wianych w niniejszym artykule projektach bardzo wyraźnie widoczne jest wzajemne przenikanie się tradycyjnych, związanych z polską szkołą projektowa, polską sztuką narodowa, dekoracyjnych warto-ści estetycznych z przynależną do nurtu awangardy i modernizmu nowoczesnością. Sowicki umiejętnie wykorzystuje charakterystyczne dla obu kierunków cechy łącząc je w spójną całość.

Na potrzeby artykułu jako główną metodę badawczą przyjęto analizę materiału wizualnego, który znajduje się w archiwum rodziny Władysława Sowickiego, a także kwerendę archiwalną i biblioteczną, przegląd literatury naukowej dotyczącej tematyki związanej z tematyką artykułu oraz analizę ewolucji stylów i tendencji z zakresu architektury w przedziale czasowym tożsamym z okresem powstania omawianych w pracy projektów.

Opisywane w artykule prace architektoniczne Sowickiego miały charakter tymczasowy, przeznaczone były do reprezentowania konkretnych podmiotów w ustalonym czasie i miejscu, nie miały wpisywać się trwale w krajobraz architektoniczny, ponieważ długość ich trwania była ściśle określona. Intencją autorki było pokazanie omawianych projektów w zestawieniu z podobnymi, powstającymi w przybliżonym czasie, posiadającymi analogiczny charakter formalny i stylistyczny. Autorka również chciała zaznaczyć, że prace Władysława Sowickiego wpisują się w kontekst i założenia pokrewnych polskich realizacji architektonicznych z drugiej połowy lat trzydziestych dwudziestolecia międzywojennego.

\footnotetext{
Agata Wereszczyńska

interior architect and designer with a doctoral degree in technical sciences in the discipline of Architecture and Urban Planning, specialized in architecture; adjunct in the Institute of Architecture by the Faculty of Civil Engineering, Architecture and Environmental Engineering of Łódź Technical University; owner of an interior architecture design studio; member of the Association of Polish Artists and Designers, regional chapter in Łódź, contact: Politechnika Łódzka Instytut Architektury, 90-924 Łódź, Al. Politechniki 6; e-mail: agata.wereszczynska@p.lodz.pl

architekt wnętrz Agata Wereszczyńska, doktor nauk technicznych w dyscyplinie naukowej architektura i urbanistyka, w specjalności architektura; adiunkt w Instytucie Architektury Wydziału Budownictwa, Architektury i Inżynierii Środowiska Politechniki Łódzkiej; właściciel pracowni projektowania architektu-ry wnętrz; członek Zwiq̨zku Polskich Artystów Plastyków Okręg Łódź kontakt: Politechnika Łódzka Instytut Architektury, Al. Politechniki 6, 90-924 Łódź; e-mail:agata.wereszczynska@p.lodz.pl
} 